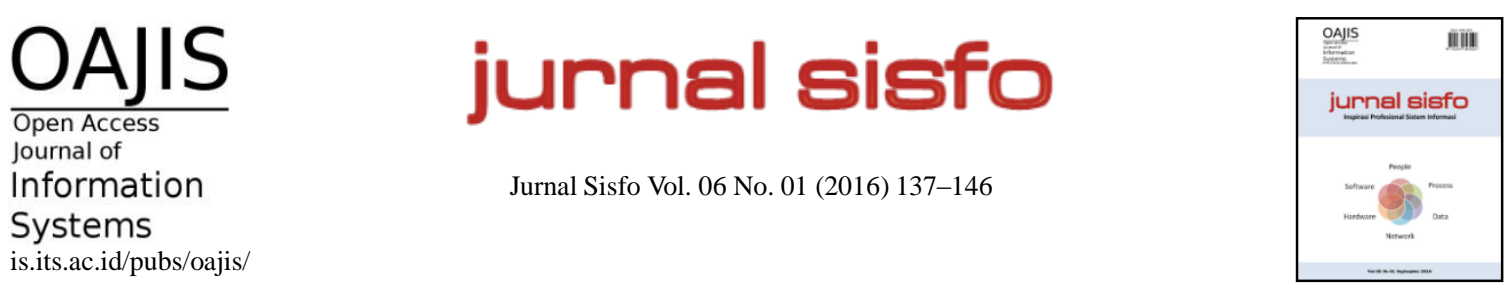

\title{
Perencanaan Kapasitas Layanan ATM Bank Jatim Berdasarkan Capacity Management ITIL V3
}

\author{
Aboeryzal Ahmed Koesyairy, Anisah Herdiyanti", Apol Pribadi Subriadi \\ Jurusan Sistem Informasi, Fakultas Teknologi Informasi, Institut Teknologi Sepuluh Nopember
}

\begin{abstract}
Bank Jatim has about 450,000 clients by the end of 2011 and is predicted to grow by $14 \%$ per year. Based on these trends, Bank Jatim ATM services are required to be available for 24 hours each day according to the quality level provided in Service Level Agreement (SLA). By doing so, the ATM services may decrease the risk of resource failure by managing its capacity. Moreover, Bank Jatim has to monitor the IT operational acivities as it is mentioned in DS3 COBIT 4.1 being used for IT governance by Bank Jatim IT division. Therefore, implementing capacity management is necessary for Bank Jatim in order to maintain the services quality and to comply with its standard. The method used in this research is following the step-by-steps to perform capacity management based on ITIL V3. The inputs for capacity management in Bank Jatim are obtained from data gathering through interview and desk observation. The results from this research are 1 (one) capacity plan, 7 (seven) capacity improvement recomendations, and 4 (four) business scenario for Bank Jatim ATM services. It contributes to enrich the implementation of capacity management and to help organization decide planning on IT-related capacity that supports ATM services.
\end{abstract}

Keywords: ATM, Capacity Management, Capacity Planning, ITIL V3

\begin{abstract}
Abstrak
Pada tahun 2011 Bank Jatim memiliki jumlah nasabah sebanyak 450000 orang yang diperkirakan akan tumbuh sebesar 14\% setiap tahunnya. Dengan kondisi tersebut, layanan ATM Bank Jatim harus memiliki tingkat ketersediaan dalam waktu 24 jam setiap harinya guna memenuhi kebutuhan bisnis dan tingkat layanan. Salah satu cara untuk menjamin ketersediaan layanan ATM Bank adalah dengan mengurangi risiko kegagalan sumber daya pendukung layanan dengan manajemen kapasitas teknologi informasi (TI). Selain itu Bank Jatim harus memenuhi kontrol pemantauan operasional TI pada DS3 COBIT 4.1 yang diacu sebagai tata kelola TI-nya. Oleh karena itu, Bank Jatim perlu melakukan manajemen kapasitas guna menjaga kualitas layanan dan memenuhi regulasi tersebut. Metode yang digunakan dalam penelitian ini mengacu kepada manajemen kapasitas berdasarkan ITIL V3. Input manajemen kapasitas pada Bank Jatim didapatkan dengan melakukan penggalian data melalui wawancara dan observasi. Hasil dari penelitian ini adalah sebuah perencanaan kapasitas, 7 (tujuh) rekomendasi peningkatan kapasitas, dan 4 (empat) skenario bisnis layanan ATM Bank Jatim. Dengan adanya perencanaan kapasitas, Bank Jatim dapat mempertimbangkan keputusan mengenai kapasitas yang berkaitan dengan TI yang mendukung layanan ATM.
\end{abstract}

Kata kunci: ATM, ITIL V3, Layanan, Manajemen Kapasitas, Perencanaan Kapasitas

(c) 2016 Jurnal SISFO.

Histori Artikel : Disubmit 25 Juli 2016; Diterima 23 September 2016; Tersedia online 24 September 2016

\footnotetext{
* Corresponding Author

Email address: anisah.herdiyanti@gmail.com (Anisah Herdiyanti)
} 


\section{Pendahuluan}

Bank Jatim memiliki jumlah nasabah sebesar 450.000 orang atau sekitar $55 \%$ dari penduduk Jawa Timur telah dilayani Bank Jatim pada akhir 2011 dan diperkirakan tumbuh sebesar 14\% per tahunnya [1]. Setiap nasabah Bank Jatim tentu akan menggunakan layanan ATM (Automatic Teller Machine) untuk melakukan pengambilan uang tunai ataupun transfer antar rekening Bank Jatim atau Bank lainnya. Jika pertumbuhan nasabah pengguna kartu ATM Bank Jatim tidak diimbangi dengan kapasitas pendukung layanan ATM, maka akan ada potensi terjadinya kegagalan sumber daya layanan ATM Bank Jatim. Dampak dari hal tersebut akan menimbulkan ketidakpuasan pelanggan dan penurunan loyalitas pelanggan terhadap Bank $[2,3]$. Karenanya Bank Jatim harus selalu menjaga tingkat ketersediaan layanan ATM selama 24 jam setiap harinya agar dapat memenuhi kebutuhan bisnis dan SLA layanan ATM Bank Jatim. Di sisi lain, Bank Jatim saat ini masih belum melakukan manajemen kapasitas layanan yang sesuai dengan standar good practice ITIL V3 [4]. Padahal jika suatu organisasi menerapkan manajemen kapasitas ITIL V3 akan mendapatkan manfaat seperti peningkatan kepuasan pelanggan, mengurangi risiko kegagalan sumber daya layanan, mengefektifkan dan mengefisiensikan anggaran belanja teknologi informasi (TI), dan memberikan pandangan ke depan bagi organisasi mengenai kapasitas kebutuhan layanan [5]. Oleh karena itu, Bank Jatim perlu melakukan manajemen kapasitas terhadap layanan ATM. Selain itu proses TI di Bank Jatim saat ini juga merujuk pada COBIT 4.1 yang menunjukkan bahwa upaya Bank Jatim untuk menstandarisasi pengelolaan TI-nya berdasarkan kerangka kerja Tata Kelola TI.

Terlepas dari kondisi terkini mengenai manajemen kapasitas TI di Bank Jatim, layanan ATM Bank Jatim kerap kali mengalami permasalahan ketidaktersediaan diantaranya disebabkan oleh perencanaan kapasitas yang belum mengakomodasi peningkatan kapasitas sesuai dengan kebutuhan pasar (demand). Berangkat dari kondisi terkini tersebut, analisis kesenjangan diperlukan untuk mengetahui kesenjangan kondisi terkini dengan standar acuan (kondisi ideal) [6] dalam manajemen kapasitas berdasarkan ITIL V3 dan kontrol pada DS3 Manage Performance and Capacity COBIT 4.1. Hasil penelitian yang diharapkan berupa manajemen kapasitas layanan ATM Bank Jatim yang berisikan perencanaan kapasitas, rekomendasi peningkatan layanan dan skenario bisnis peningkatan layanan ATM Bank Jatim. Penelitian ini dapat memberikan manfaat bagi Bank Jatim berupa kepastian untuk ketersediaan layanan ATM Bank Jatim melalui perencanaan kapasitas yang mengakomodasi kebutuhan sumber daya pendukung layanan hingga beberapa tahun ke depan [5].

\section{Tinjauan Pustaka}

Tinjauan pustaka digunakan sebagai dasar pengerjaan penelitian ini. Tinjauan pustaka dari penelitian adalah sebagai berikut.

\subsection{Capacity Management}

Manajemen kapasitas didefinisikan sebagai suatu proses yang dapat memperpanjang jangka waktu suatu layanan TI yang dimiliki organisasi dan akan memastikan TI yang diinvestasikan organisasi tersebut terjustifikasi biayanya [5, 7]. Sedangkan menurut referensi lain [8], manajemen kapasitas merupakan suatu penyediaan kapasitas TI dalam rangka memenuhi kebutuhan pelanggan terhadap layanan TI dalam jangka waktu aktual dan masa yang akan datang dengan menyeimbangkannya terhadap biaya yang diinvestasikan. Tujuan dari dilakukannya manajemen kapasitas yakni untuk memastikan kapasitas TI yang telah terjustifikasi biayanya pada semua area TI selalu tersedia dan sesuai dengan kebutuhan bisnis saat ini dan masa yang akan datang $[9,10]$. Manajemen kapasitas menurut ITIL V3 memiliki tiga sub proses yang terdapat aktivitas disetiap sub proses tersebut. Tiga sub proses manajemen kapasitas antara lain Business Capacity Management, Service Capacity Management, dan Component Capacity Management. Business Capacity Management bertujuan untuk menerjemahkan dari kebutuhan dan rencana bisnis ke dalam kebutuhan layanan dan infrastruktur TI. Service Capacity Management bertujuan untuk mengidentifikasi 
dan mengerti penggunaan sumber daya dan pola kerja terhadap layanan TI untuk mencapai target SLA. Component Capacity Management bertujuan untuk manajemen, kontrol, dan prediksi dari kinerja, pemanfaatan, dan kapasitas dari individual komponen TI yang ada pada perusahaan yang berkaitan layanan. Sedangkan aktivitas manajemen kapasitas antara lain performance management, demand management, application sizing, modelling, Storage of Capacity Management Data, Capacity Planning, dan Reporting.

Penelitian terdahulu menggunakan berbagai model untuk perencanaan kapasitas, diantaranya untuk keputusan penambahan kapasitas (capacity expansion decision) [11], optimasi produksi [12], hingga economic models untuk layanan [13]. Modelling pada penelitian ini menggunakan metode Holt Linear Exponential Smoothing dengan rumus [14].

$$
\begin{aligned}
& L_{t}=\alpha Y_{t}+(1-\alpha)\left(L_{t-1}+b_{t-1}\right) \\
& b_{t}=\beta\left(L_{t}-L_{t-1}\right)+(1-\beta) b_{t-1} \\
& F_{t+m}=L_{t}+b_{t} m
\end{aligned}
$$

Selain itu untuk mendapatkan prediksi dari penggunaan server Bank Jatim, penelitian ini menggunakan metode regresi dengan rumus [15]

$Y=a+b X$

Keterangan :

$Y=$ Variabel Tidak Bebas (Dependent)

$X=$ Variabel Bebab (Independent)

$a=$ konstanta

$b=$ koefisien regresi (kemiringan)

\subsection{Gap Analysis}

Analisis kesenjangan merupakan suatu metode untuk membantu suatu organisasi dalam mengetahui kesenjangan atau mengukur perbedaan antara kondisi saat ini dengan kondisi yang diharapkan [16]. Analisis gap dilakukan untuk mendapatkan rekomendasi peningkatan, diantaranya untuk peningkatan proses bisnis [17], peningkatan kepuasan [18] maupun peningkatan kapasitas [19].

Analisis kesenjangan memiliki dua poin penting yaitu as-is dan to-be. As-is merupakan suatu kondisi terkini yang dimiliki oleh suatu organisasi sedangkan to-be merupakan kondisi yang diharapkan organisasi tersebut. Menurut Parker [20],terdapat tiga pengklasifikasian manfaat atau dampak dari pengaplikasian SI/TI antara lain tangible benefit, quasi benefit, dan intangible benefit.

Tabel 1. Pemetaan aktivitas manajemen kapasitas ITIL V3 dan DS3 COBIT 4.1

\begin{tabular}{cl}
$\begin{array}{c}\text { Aktivitas Manajemen } \\
\text { kapasitas ITIL V3 }\end{array}$ & \multicolumn{1}{c}{ Control objective DS3 manage performance and capacity COBIT 4.1 } \\
\hline \multirow{2}{*}{ Performance monitoring } & $\begin{array}{l}\text { Penilaian terhadap kinerja dan kapasitas sumber daya TI secara aktual } \\
\text { Terdapat mekanisme toleransi kesalahan sumber daya TI } \\
\text { Pemantauan secara terus menerus terhadap kinerja dan kapasitas sumber daya TI }\end{array}$ \\
& $\begin{array}{c}\text { Kapasitas dan kinerja sesuai kebutuhan bisnis dan memperhitungkan aspek beban kerja, } \\
\text { kentingensi, penyimpanan, siklus hidup sumber daya TI } \\
\text { Demand Management }\end{array}$ \\
Terdapat pengalokasian sumber daya TI
\end{tabular}




\begin{tabular}{|c|c|}
\hline $\begin{array}{l}\text { Aktivitas Manajemen } \\
\text { kapasitas ITIL V3 }\end{array}$ & Control objective DS3 manage performance and capacity COBIT 4.1 \\
\hline \multirow{2}{*}{ Modelling } & $\begin{array}{l}\text { Terdapat pemodelan yang jelas dalam melakukan perencanaan kapasitas dan kinerja } \\
\text { sumber daya TI }\end{array}$ \\
\hline & Peramalan terhadap kapasitas dan kinerja sumber daya TI \\
\hline & Data hasil pemantauan memiliki tujuan melaporkan ketersediaan layanan sesuai SLA \\
\hline $\begin{array}{l}\text { Storage of capacity } \\
\quad \text { management }\end{array}$ & $\begin{array}{l}\text { Data hasil pemantauan memiliki tujuan memelihara dan menyesuaikan kinerja, beban } \\
\text { kerja layanan, rencana penyimpanan, akuisisi sumber daya }\end{array}$ \\
\hline Capacity planning & Terdapat proses perencanaan dalam peninjauan kapasitas dan kinerja sumber daya TI \\
\hline Reporting & $\begin{array}{l}\text { Peninjauan dari pihak manajemen dalam memastikan rencana kemungkinan yang terjadi } \\
\text { telah mengatasi aspek ketersediaan, kapasitas dan kinerja sumber daya TI }\end{array}$ \\
\hline
\end{tabular}

\subsection{Pemetaan Aktivitas Manajemen Kapasitas ITIL V3 dan DS3 COBIT 4.1}

Pemetaan aktivitas manajemen kapasitas ITIL V3 dan DS3 COBIT 4.1 digunakan sebagai dasar instrumen dalam penggalian data, analisis kesenjangan, dan acuan dalam rekomendasi peningkatan layanan ATM Bank Jatim. Pemetaan aktivitas manajemen kapasitas ITIL V3 terhadap DS3 COBIT 4.1 berdasarkan "Aligining COBIT 4.1, ITIL V3 and ISO/IEC27002 for Business Benefit" [21]. Tabel 1 mendaftar hasil pemeteaan aktivitas manajemen kapasitas ITIL V3 dan DS3 COBIT 4.1.

\subsection{ATM Bank Jatim}

Automatic Teller Machine (ATM) merupakan salah satu layanan TI yang ada pada sektor perbankan. ATM adalah alat telekomunikasi terkomputasi yang menyediakan akses layanan transaksi finansial nasabah tanpa adanya perantara kasir ataupun teller bank [22]. Bank Jatim juga menyediakan layanan ATM bagi nasabahnya. Layanan ATM Bank Jatim dapat diakses dengan menggunakan kartu ATM yang dimiliki oleh setiap nasabah Bank Jatim. Dengan menggunakan ATM Bank Jatim maka nasabah dapat menikmati beberapa layanan berikut [23]:

1) Melakukan transaksi uang, transfer, pengecekan saldo, dan pembayaran untuk Telkom, PBB, HP, SPP dan pembelian online

2) Penarikan uang dari setiap ATM yang berlogo Prima dan ATM Bersama

3) Pembelian di merchant berlogo Prima debit dan BCA debit

ATM Bank Jatim dapat digunakan dalam jaringan Bank sebagai berikut:

1) ATM Prima : BCA, BII, Permata, OCBC NISP, Mega

2) ATM Bersama : Mandiri, BNI 46, CIMB Niaga, HSBC, Panin, Danamon

\section{Metodologi}

Metode penelitian dibuat sebagai acuan agar pengerjaan penelitian menjadi terstruktur. Pada Gambar 1 dipaparkan mengenai tahapan atau proses yang akan dilakukan dalam penelitian ini. Pengerjaan penelitian ini terdiri dari 5 (lima) aktivitas utama, yaitu: a) penggalian data, b) analisis kesenjangan kondisi terkini manajemen kapasitas terhadap kondisi ideal manajemen kapasitas ITIL V3, c) manajemen kapasitas, d) rekomendasi peningkatan layanan, dan e) penentuan skenario bisnis peningkatan layanan. Penggalian data dilakukan dengan interview dan observasi sementara analisis kesenjangan dilakukan dengan mendaftar aktivitas yang belum sesuai dengan kondisi ideal beradasarkan capacity management ITIL V3. Selanjutnya 
manajemen kapasitas dibuat dengan melakukan 3 (tiga) sub aktivitas, yaitu: c.1) analisis dan prediksi kapasitas bisnis layanan, c.2) analisis dan prediksi kapasitas penyampaian layanan kepada pengguna, serta c.3) analisis dan prediksi kapasitas sumber daya layanan. Selanjutnya rekomendasi peningkatan layanan didapatkan setelah sebelumnya memvalidasi dengan pihak divisi TI Bank Jatim. Setelah didapatkan rekomendasi peningkatan layanan diidentifikasi skenario bisnis untuk setiap rekomendasi peningkatan layanan ATM Bank Jatim.

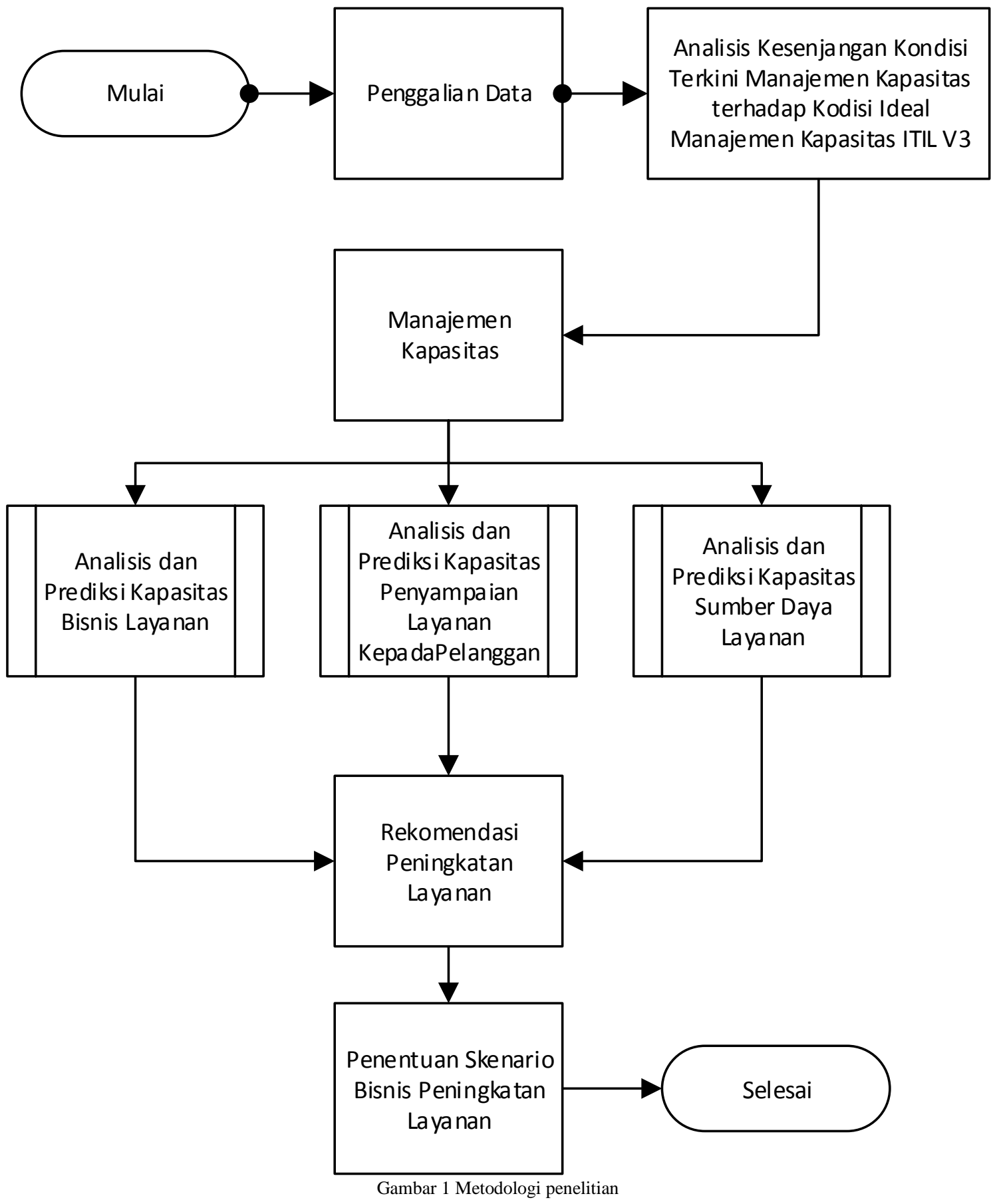




\section{Hasil dan Pembahasan}

Bagian ini menjelaskan hasil yang didapatkan dari penelitian ini, dan pembahasan secara keseluruhan yang didapatkan dari penelitian. Adapun pembahasan akan difokuskan kepada hasil penelitian ke dalam 6 (enam) paparan utama, yaitu: 1) analisis kesenjangan kondisi terkini manajemen kapasitas terhadap kondisi ideal manajemen kapasitas ITIL V3; manajemen kapasitas yang akan dipaparkan melalui sub aktivitasnya, yaitu: 2) analisis dan prediksi kapasitas bisnis layanan, 3) analisis dan prediksi kapasitas penyampaian layanan kepada pengguna, serta 4) analisis dan prediksi kapasitas sumber daya layanan; 5) rekomendasi peningkatan layanan; serta 6) penentuan skenario bisnis peningkatan layanan.

\subsection{Analisis Kesenjangan Kondisi Terkini Manajemen Kapasitas terhadap Kondisi Ideal Manajemen Kapasitas ITIL V3}

Analisis kesenjangan didapatkan dari hasil analisis kondisi kekinian manajemen kapasitas layanan ATM Bank Jatim. Penemuan kesenjangan tersebut dilihat dari kelemahan atau kekurangan yang ada di kondisi saat ini yang belum memenuhi kondisi aktivitas manajemen kapasitas ITIL V3 dan kontrol DS3 COBIT 4.1. Hasil analisis kesenjangan didapatkan tiga aktivitas manajemen kapasitas yang belum sesuai dengan kondisi ideal antara lain :

1) Modelling. Aktivitas modelling belum dilakukan oleh divisi TI Bank Jatim untuk layanan ATM Bank Jatim terutama pada prediksi pengguna kartu ATM Bank Jatim. Berdasarkan kondisi ideal, manajemen kapasitas memerlukan adanya adanya pemodelan dan peramalan pertumbuhan pengguna ATM Bank Jatim. Nantinya aktivitas ini akan dibahas pada sub proses Component Capacity Management.

2) Capacity Planning. Perencanaan kapasitas layanan ATM Bank Jatim sebelumnya pernah dilakukan namun tidak dilakukan secara berkala sehingga perencanaan kapasitas yang dibuat tidak sesuai dengan permintaan bisnis. Karenanya diperlukan pembuatan perencanaan kapasitas harus dilakukan pembaruan/update secara berkala. Aktivitas ini menjadi masukan dalam peningkatan layanan ATM Bank Jatim.

3) Reporting. Terdapat prosedur untuk pelaporan namun belum dilakukan pada layanan ATM Bank Jatim. Pelaporan tersebut juga terdapat verifikasi dan validasi oleh pihak divisi TI Bank Jatim tetapi belum dipatuhi. Oleh karena itu, diperlukan adanya pelaporan dokumen perencanaan kapasitas yang diverifikasi dan divalidasi oleh pihak manajemen yakni kepala divisi TI Bank Jatim. Aktivitas ini menjadi masukan dalam peningkatan layanan ATM Bank Jatim.

\subsection{Analisis dan Prediksi Kapasitas Bisnis Layanan}

Analisis dan prediksi kapasitas bisnis layanan atau yang dikenal dengan Business Capacity Management, dilakukan dengan mengacu kepada rencana jangka panjang Bank Jatim mengenai pengembangan produk dan jasa perbankan berbasis TI untuk meningkatkan fee base income dan jangka menengah dan pendek mengenai persiapan sistem TI yang mendukung aktivitas pelayanan Bank maka Bank Jatim [1]. Mengacu pada kebutuhan bisnis tersebut maka jumlah ATM Bank Jatim harus ditingkatkan dan diperlukan adanya rencana kapasitas infrastruktur pendukung layanan ATM Bank Jatim. Selain itu, kinerja keuangan giro pada Bank lain mengalami peningkatan sebesar 58,02\% seiring dengan meningkatnya pengguna kartu ATM Bank Jatim pada akhir 2015. Jadi agar pendapatan dari giro Bank lain terus meningkat, Bank Jatim perlu untuk memperluas jaringan kerjasama pada ATM Bersama dan Prima guna memperluas pasar. Di sisi lain, pada Februari 2016 jumlah pengguna kartu ATM Bank Jatim sebesar 1.133.879 orang. Diprediksi pertumbuhan rata-rata per bulan jumlah pengguna kartu ATM Bank Jatim yakni sebesar 0,01\%. Diperkirakan pada januari tahun 2020 jumlah pengguna kartu ATM Bank Jatim akan mencapai 1.685.058 orang. Hasil analisis dan prediksi sub proses business capacity management dijadikan masukan dalam melakukan component capacity management dan rekomendasi peningkatan layanan ATM Bank Jatim. 


\subsection{Analisis dan Prediksi Kapasitas Penyampaian Layanan kepada Pengguna}

Sub aktivitas analisis dan prediksi kapasitas penyampaian layanan kepada pengguna menggambarkan aktivitas Service Capacity Management pada ITIL V3 [5] yang memberikan analisis kapasitas dari penyampaian layanan ATM Bank Jatim kepada pengguna kartu layanan ATM Bank Jatim dan memastikan SLA layanan terpenuhi. Berikut hasil analisis sub proses Service Capacity Management antara lain :

1) Saat ini jumlah fasilitas ATM Bank Jatim telah mencukupi terhadap persebaran penguna kartu ATM Bank Jatim karena setiap daerah persebaran pengguna kartu ATM Bank Jatim sudah terdapat fasilitas mesin ATM Bank Jatim baik yang stand alone ataupun pada kantor cabang. Selain itu stiap fasilitas mesin ATM telah terutilitasi.

2) Kurang efektif dan efisiennya pembuatan kartu ATM Bank Jatim yang dilakukan terpusat di kantor pusat. Hal tersebut terjadi karena pembuatan dan penyaluran kartu ATM Bank Jatim yang terpusat dinilai lambat dan memakan waktu yang cukup lama sehingga kepuasan nasabah berpotensi menurun.

3) Seringkali adanya kekosongan staff dalam melakukan perbaikan fasilitas ATM sehingga permasalahan tersebut tidak terselesaikan secara cepat dan dapat ditinggalkan begitu saja. Di sisi lain, teknisi dari pihak vendor terkadang juga tidak tersedia. Hal tersebut berdampak pada ketersediaan fasilitas ATM Bank Jatim yang terkadang mengalami offline dengan waktu lama dan penyelesaian permasalahan ATM tidak maksimal.

4) Namun SLA pengelolaan komponen fisik dan jaringan selalu terpenuhi sebesar $99 \%$

Hasil analisis pada sub proses ini digunakan dalam masukan untuk rekomendasi peningkatan layanan ATM Bank Jatim.

\subsection{Analisis dan Prediksi Kapasitas Sumber Daya Layanan}

Component capacity management berdasarkan ITIL V3 mencakup analisis dan prediksi kapasitas sumber daya layanan. Hal ini mencakup analisis dan prediksi pada kapasitas komponen pendukung layanan. Dari segi infrastruktur, kondisi komponen jaringan layanan ATM Bank Jatim telah terutilisasi 100\% namun masih terdapat cabang Bank Jatim yang masih memasang komponen jaringan tidak sesuai dengan spesifikasi Divisi TI [4]. Selain itu, kondisi terkini pada kondisi server sistem production ATM Bank Jatim yakni terdapat permasalahan adanya penurunan kinerja pada awal dan akhir bulan karena proses end of month dan penarikan gaji PNS.

Hasil prediksi dari komponen ATM Bank Jatim dilakukan dengan metode regresi menggunakan variabel bebas pertumbuhan jumlah pengguna kartu ATM Bank Jatim terhadap penggunaan CPU dan storage server production dan DRC layanan ATM Bank Jatim. Hasil prediksi pada server production yakni penggunaan rata-rata CPU server production diperkirakan akan melebihi batas penggunaan pada bulan Desember 2018 karena penggunaan rata-rata CPU melebihi 70\%. Selain itu kenaikan rata-rata penggunaan CPU server production per bulan yakni mencapai $0,09 \%$. Namun penggunaan rata-rata CPU server production dapat melebihi batas sebelum desember 2018 dikarenakan pada data historis pernah terjadi peningkatan penggunaan rata-rata CPU secara signifikan. Pada prediksi storage server production diperkirakan akan terus aman hingga januari 2020. Namun Divisi TI harus tetap waspada karena prediksi tersebut tidak mempertimbangkan peningkatan jumlah data jika terdapat suatu event seperti pendaftaran CPNS.

Hasil prediksi pada server DRC antara lain penggunaan rata-rata CPU server DRC diperkirakan tetap aman hingga januari 2020. Rata-rata pertumbuhan per bulan dari penggunaan rata-rata CPU server DRC diperkirakan sebesar 0,2\%. Namun Divisi TI harus tetap waspada karena pada data historis pernah terjadi peningkatan penggunaan storage secara signifikan. Sedangkan untuk penggunaan storage akan tetap aman setelah dilakukan prediksi hingga januari 2020. Rata-rata pertumbuhan per bulan rata-rata penggunaan 
storage server DRC yakni sebesar 0,03\%. Untuk server DRC, Divisi TI harus tetap waspada karena pada data historis pernah terjadi peningkatan penggunaan storage secara signifikan.

Hasil dari component capacity management digunakan sebagai masukan pada rekomendasi peningkatan layanan ATM Bank Jatim.

\subsection{Rekomendasi Peningkatan Layanan ATM Bank Jatim}

Rekomendasi peningakatan layanan ATM Bank Jatim didapatkan berdasarkan temuan dari hasil manajemen kapasitas yang terdiri dari analisis kesenjangan, sub proses Business Capacity Management, Service Capacity Management, dan Component Capacity Management. Rekomendasi peningkatan layanan ATM Bank Jatim tersebut divalidasi oleh pihak IT Planning dan IT Development Bank Jatim. Terdapat tujuh rekomendasi peningkatan layanan ATM Bank Jatim yang sesuai dengan kondisi divisi TI Bank Jatim yakni :

1) Pembuatan model dan peramalan terhadap data-data perencanaan kapasitas layanan ATM bank Jatim yang didukung dengan sumber daya aplikasi Ms. Excel, data pengguna kartu ATM, data transaksi pengguna layanan ATM Bank Jatim, number of account layanan ATM Bank Jatim, penggunaan ratarata CPU server sistem production dan DRC, utilitas storage server sistem production dan DRC, dan staff IT Planning

2) Pembuatan kebijakan dan prosedur mengenai perencanaan kapasitas layanan TI yang dilakukan dan ditinjau secara berkala yang didukung sumber daya prosedur perencanaan kapasitas Divisi TI Bank Jatim dan staff IT Planning

3) Pembuatan laporan perencanaan kapasitas layanan ATM Bank Jatim yang diverifikasi dan divalidasi kepada pihak penyelia IT Planning dan kepala divisi TI yang didukung sumber daya template laporan Ms. Word, prosedur perencanaan kapasitas Divisi TI Bank Jatim, dan staff IT Planning

4) Pengembangan aplikasi monitioring ketersediaan ATM Bank Jatim yang dapat menghitung tingkat ketersediaan layanan ATM Bank Jatim dapat membantu peningkatan layanan ATM Bank Jatim yang didukung sumber daya Informasi status ketersediaan ATM Bank Jatim, detail kapasitas uang (saldo) dan receipt setiap ATM Bank Jatim, tingkat ketersediaan ATM Bank Jatim, alokasi proporsi dana, dan staff IT Development.

5) Penambahan processor menjadi 6-core $3.6 \mathrm{GHz}$, dapat menurunkan beban penggunaan rata-rata CPU server sistem production yang didukung dengan konfigurasi sistem server production power7 720 dan alokasi proporsi dana

6) Aksi preventif dengan melakukan penambahan kapasitas storage server sistem Production menjadi 7.2 TB sehingga kenaikan storage akan selalu berada di bawah batas utilitas storage yang ditentukan. Rekomendasi peningkatan layanan ini didukung dengan konfigurasi sistem server production power7 720 dan alokasi proporsi dana

\subsection{Penentuan Skenario Bisnis Peningkatan Layanan}

Beberapa rekomendasi peningkatan layanan ATM Bank Jatim yang telah ditentukan membutuhkan skenario bisnis untuk dilakukan. Skenario bisnis untuk rekomendasi peningkatan layanan ATM Bank Jatim antara lain :

1) Pengembangan aplikasi monitoring ketersediaan ATM Bank Jatim dengan pihak vendor untuk pengembangan aplikasi monitioring ketersediaan ATM Bank Jatim

2) Pengaktifan lisensi core yang tersedia untuk processor 6 core untuk penambahan processor menjadi 6core $3.6 \mathrm{GHz}$ pada server production

3) Pengadaan aset DASD 7.2TB untuk penambahan kapasitas storage server sistem Production menjadi $7.2 \mathrm{~TB}$

4) Penambahan aset $\mathrm{I} / \mathrm{O}$ controller untuk penambahan kapasitas storage server sistem Production menjadi $7.2 \mathrm{~TB}$ 
5) Pengadaan aset memori 128 GB untuk peningkatan kapasitas memori processor menjadi 128 GB

\section{Kesimpulan}

Pada bagian ini dipaparkan hasil simpulan dari penelitian yang dilakukan. Selain itu dipaparkan saran yang bermanfaat untuk penelitian di masa yang akan datang.

\subsection{Simpulan}

Berdasarkan hasil penelitian, maka dapat disimpulkan bahwa terdapat 3 (tiga) dari 7 (tujuh) aktivitas manajemen kapasitas divisi TI Bank Jatim yang belum sesuai dengan manajemen kapasitas ITIL V3. Hasil analisis kesenjangan yakni Modelling menjadi masukan dalam perencanaan kapasitas layanan ATM Bank Jatim yang dilakukan pada sub proses component capacity management. Sedangkan pada aktivitas capacity planning dan reporting yang belum sesuai dengan ITIL V3 menjadi masukan pada rekomendasi peningkatan layanan ATM Bank Jatim.

Hasil analisis dan prediksi dari sub proses capacity management menjadi masukan untuk mengidentifikasi rekomendasi peningkatan layanan ATM Bank Jatim. Dari hasil validasi didapatkan 7 (tujuh) rekomendasi peningkatan layanan ATM Bank Jatim yang sesuai dengan kondisi divisi TI Bank Jatim. Terdapat tiga rekomendasi peningkatan layanan ATM Bank Jatim berdasarkan analisis kesenjangan, satu rekomendasi peningkatan layanan dari service capacity management, dan tiga rekomendasi peningkatan layanan ATM Bank Jatim dari component capacity management layanan ATM Bank Jatim yang berupa perencanaan kapasitas pada disk storage, memori, dan processor server production. Rekomendasi peningkatan layanan dari sisi kapasitas komponen dan kapasitas layanan ATM Bank jatim diperlukan skenario bisnis karena adanya pengadaan aset dan kerjasama dengan pihak vendor.

\subsection{Saran}

Saran yang dapat penulis sampaikan untuk penelitian selanjutnya adalah :

1) Hasil identifikasi analisis kesenjangan dari aktivitas manajemen kapasitas yang dilakukan Divisi TI Bank Jatim terhadap layanan ATM Bank Jatim dilakukan penghitungan manfaat terhadap perubahan manajemen kapasitas pada layanan ATM Bank Jatim.

2) Penelitian selanjutnya dapat menggunakan variabel transaksi pengguna layanan ATM Bank Jatim untuk menambah akurasi dari prediksi kapasitas yang dilakukan dalam melakukan prediksi kapasitas layanan ATM Bank Jatim. Serta mempertimbangkan variabel penggunaan memori dan proses I/O untuk meningkatkan hasil dari component capacity management.

\section{Daftar Rujukan}

[1] PT Bank Pembangunan Daerah Jawa Timur, "Initial Public Offering," Surabaya, 2012.

[2] H. A. Akgam, "Study of Customer Satisfaction in the Bankgin Sector in Libya," no. Banking Sector, 2012.

[3] S. Sattar, June 2014. [Online]. Available: http://nation.com.pk/business/09-Jun-2014/role-of-it-in-banking-sector, 19 January 2016.

[4] A. S. Nugraha, "Interview Tugas Akhir Bank Jatim," Surabaya, 2015.

[5] S. Taylor, V. Lloyd and C. Rudd, ITIL V3 - Service Design, 1 edition ed., The Stationery Office, 2007.

[6] A. Tanovic and N. E. Mastorakis, "Advantages of the implementation of Service Desk based on ITIL ramework in telecommunication industry," International Journal of Economics and Management Systems, vol. 1, pp. 81-86, 2016.

[7] R. Fronsheiser, "ITIL Capacity Management : Much More Than Charts Over Coffee".

[8] A. d. Jong, A. Kolthof, M. Pieper, R. Tjassing, v. d. A. Veen and T. Verheijen, ITIL V3 Foundation Exam - Study Guide, First edition, first impression, November 2008 ed., J. v. Bon, Ed., Van Haren Publishing, Zaltbommel, www.vanharen.net, 2008.

[9] I. M. Gerard Blokdijk, Capacity Management Handbook: Monitor, Analyze, Tune, Manage Demand and Plan Your Organizations IT Capacity Demands Best Practices Handbook, Emereo Publishing, 2008.

[10] J. Kurz, "Capacity planning for a maintenance service provider with advanced," ELSEVIER, November 2015. 
[11] C.-F. Chien and J.-N. Zheng, "Mini-max regret strategy for robust capacity expansion decisions in semiconductor manufacturing," Journal of Intelligent Manufacturing, vol. 23, no. 6, p. 2151-2159, 2012.

[12] S. Liu and L. G. Papageorgiou, "Multiobjective optimisation of production, distribution and capacity planning of global supply chains in the process industry," Omega, vol. 41, no. 2, p. 369-382, 2013.

[13] R. Pal and P. Hui, "Economic models for cloud service markets: Pricing and Capacity planning," Theoretical Computer Science, vol. 496, pp. 113-124, 2013.

[14] R. Hyndman, A. B. Koehler, J. K. Ord and R. D. Snyder, Forecasting with Exponential Smoothing : The State Space Approach, 2008.

[15] A. Subroto, "Analisis Faktor-Faktor Yang Mempengaruhi Minat Nasabah Pada Penggunaan Fasilitas Anjungan Tunai Mandiri (ATM) pada Bank Central Asia (BCA).".

[16] M. J, The Gap Analysis Process To Improve IT Management, 2000.

[17] D. Pajk and A. Kovacic, "Fit Gap Analysis - The Role of Business Process Reference Models," Economic and Business Review for Central and South - Eastern Europe, vol. 15, no. 4, pp. 319-338, 2013.

[18] G. Arabatzis and E. Grigoroudis, "Visitors' satisfaction, perceptions and gap analysis: The case of Dadia-Lefkimi-Souflion National Park," Forest Policy and Economics, vol. 12, no. 3, p. 163-172, 2010.

[19] X.-N. Zhou, R. Olveda, B. Sripa, G.-J. Yang, L. Leonardo and R. Bergquist, "From gap analysis to solution and action: The RNAS+ model," Acta Tropica, vol. 141, p. 146-149, 2015.

[20] P. M. M, B. R. J and T. H. E, Information Economics: Linking Business Performance to Information Technology, Prentice Hall, 1988.

[21] G. Hardy and J. Heschl, Aligning COBIT 4.1, ITIL V3 and ISO/IEC 27002 for Business Benefit, ITGI, ISACA, TSO, 2008.

[22] Omari and R. K. Bamfo, "An Assesment of the Use of Automated Teller Machine (ATM) of Barclays Bank Ghana Limited Akim Oda Branch," September 2012.

[23] Bank Jatim, 2015. [Online]. Available: https://www.bankjatim.co.id/en/conventional/product-services/services/atm, 19 January 2016. [Accessed 1901 2016]. 